\title{
Antimicrobial susceptibility and resistance mechanisms of methicillin resistant Staphylococcus aureus isolated from 12 Hospitals in Turkey
}

Ömer Yıldız', Ahmet Yılmaz Çoban², Aslı Gamze Şener ${ }^{3}$, Seher Ayten Coşkuner ${ }^{4}$, Gülçin Bayramoğlư Hüseyin Güdücüoğlu ${ }^{6}$, Mustafa Özyurtt ${ }^{7}$, Müşerref Tatman-Otkun ${ }^{8}$, Nihal Karabiber ${ }^{9}$, Nuri Özkütük ${ }^{10}$, Orhan Aktepe ${ }^{11}$, Serkan Öncü ${ }^{12}$, Uğur Arslan ${ }^{13}$ and Bülent Bozdoğan ${ }^{1,14^{*}}$

\begin{abstract}
Introduction: Methicillin-resistant Staphylococcus aureus (MRSA) is one of the most important nosocomial pathogens and is also emerging in Turkish hospitals. The aim of this study was to determine the antimicrobial susceptibility profiles of MRSA isolated from Turkish hospitals.

Materials and methods: A total of 397 MRSA strains isolated from 12 hospitals in Turkey were included to present study. Antimicrobial susceptibilities were tested using agar dilution method. Presence of ermA, ermB, ermC, msrA, tetM, tetK, linA and aac-aph genes were studied by PCR.

Results: All strains were susceptible to vancomycin and linezolid. The susceptibility rates for fusidic acid, lincomycin, erythromycin, tetracyclin, gentamycin, kanamycin, and, ciprofloxacin were $91.9 \%, 41.1 \%, 27.2 \%, 11.8 \%, 8.5 \%, 8.3 \%$ and 6.8\%, respectively. Lincomycin inactivation was positive for 3 isolates. Of 225 erythromycin resistant isolates 48 had ermA, 20 had ermC, and 128 had ermA-C. PCR was negative for 15 strains. Of 3 isolates with lincomycin inactivation one had linA and msrA. Of 358 gentamycin resistant isolates 334 had aac-aph and 24 were negatives. Among 350 tetracyclin resistant isolates 314 had tetM. Of 36 tetM negative isolates 10 had tetK.

Conclusion: MRSA isolates from Turkish hospitals were multiresistant to antimicrobials. Quinolone and gentamycin resistance levels were high and macrolide and lincosamide resistance were relatively low. Susceptibility rates for fusidic asid were high. Linezolide and vancomycin resistance are not emerged. The most common resistance genes were ermA, tetM and aac-aph. Evolution of antimicrobial susceptibilities and resistance genes profiles of MRSA isolates should be surveyed at regional and national level for accurate treatment of patients and to control dissemination of resistance genes.
\end{abstract}

Keywords: Staphylococci, MRSA, Antimicrobial susceptibility, Resistance mechanisms, PCR

\section{Introduction}

Staphylococci are important infection agents that cause hospital and community acquired infections. These bacteria have ability to adapt themselves to difficult conditions and successful clones have capacity of epidemic and pandemic dissemination [1]. Increasing resistance problem in staphylococci became an important public

\footnotetext{
* Correspondence: bbozdogan@gmail.com

'ADU BILTEM Epidemiology Unit, Aydin, Turkey

${ }^{14}$ Medical Faculty, Medical Microbiology Department, Adnan Menderes University, 09010 Aydin, Turkey

Full list of author information is available at the end of the article
}

health problem. In 1944 when penicillin became available for use the susceptibility rate of Staphylococcus aureus to penicillin was $>94 \%$ which became $<5 \%$ recently [2]. Methicillin resistance appeared and started to disseminate from 1980 and became one of the major problem in hospital infections. Methicillin resistance is due to acquisition of a transpeptidase, PBP2a, involved in cell wall synthesis that has low affinity for beta lactam antibiotics which rends bacteria resistant to all beta lactam antibiotics. Treatment of infections due to methicillin resistant $S$. aureus (MRSA) causes problems due to restricted number of choices [1]. Especially from 2003, when vancomycin

\section{Ciomed Central}

(c) 2014 Yıldız et al.; licensee BioMed Central Ltd. This is an Open Access article distributed under the terms of the Creative Commons Attribution License (http://creativecommons.org/licenses/by/4.0), which permits unrestricted use, distribution, and reproduction in any medium, provided the original work is properly credited. The Creative Commons Public Domain Dedication waiver (http://creativecommons.org/publicdomain/zero/1.0/) applies to the data made available in this article, unless otherwise stated. 
resistant S. aureus emerged it became urgent to search new treatment possibilities for these bacteria [3]. In addition emergence and dissemination of community MRSA isolates forced to evaluate empiric treatment options in consideration with changing resistance profiles of these bacteria. MRSA strains do not affect only human but also infect farm animals and pets [4]. Although development of new antibiotics reduced dramatically recently, some antibiotics like daptomycin, linezolid and tigecyclin could be commercialized lately [1].

In the present study susceptibilities of 397 MRSA isolated from 12 centers in Turkey to linezolid, fusidic acid, kanamycin, gentamycin, erythromycin, lincomycin, tetracyclin, vancomycin and ciprofloxacin were tested by agar dilution method and presence known resistance genes were verified by PCR using specific primers.

\section{Materials and methods}

A total of 12 centers from 11 cities participated to the present study and sent MRSA isolates to Aydin where susceptibility testing and molecular studies were done at ADU BILTEM Epidemiology Unit. Methicillin resistance was confirmed by cefoxitin disc method. A total of 397 MRSA isolates were collected from hospitalized patients between 2006-2008, from Aydın (15 isolates), Izmir (2 centres 17 and 22 isolates), Afyon (32), Manisa (23), Van (42), Trabzon (54), Samsun (51), Ankara (31), Konya (28), Istanbul (55), and Edirne (36).

\section{Determination of antimicrobial susceptibilities Agar dilution method}

Antibiotics tested were linezolid, fusidic acid, kanamycin, gentamycin, erythromycin, lincomycin, tetracyclin, vancomycin and ciprofloxacin. Erythromycin and fusidic acid were from Koçak Farma (Tekirdağ, Türkiye), kanamycin, tetracyclin and vancomycin were purchased from Sigma, and commercial injectable preparations were used for the remaining antimicrobials. Agar dilution method was used as described previously [5]. Shortly plates were prepared with serial dilution from 64 or $128 \mathrm{mg} / \mathrm{L}$ antibiotic concentrations. Inoculum with $5 \times 10^{4}$ bacteria was placed onto agar using multipoint inoculator. After 16-20 h incubation at $37^{\circ} \mathrm{C}$ the lowest concentration that inhibits bacterial growth was accepted as MIC. Reference strain $S$. aureus RN4220 was included to each run.

\section{Gots test}

All lincomycin resistant isolates were tested by Gots' test for presence of resistance by antibiotic inactivation. For this purpose to $19 \mathrm{ml}$ agar at $50-60^{\circ} \mathrm{C} 19 \mathrm{ml} \mathrm{BHI}$ (Brain Heart infusion) agar $0,5 \mathrm{mg} / \mathrm{L}$ clindamycin and $1 \mathrm{ml}$ overnight broth of Micrococcus luteus ATCC9341 were added, mixed and poured to petri dish and left for solidification. The MRSA isolates were inoculated as small round onto agar. On one plate approximately 20 MRSA isolates were inoculated. After $24 \mathrm{~h}$ incubation at $37^{\circ} \mathrm{C}$ plates were left $24 \mathrm{~h}$ at room temperature. Growth of indicator bacteria in the round of tested bacteria was accepted as positive which showed presence of resistance mechanism by inactivation [6].

\section{Determination of resistance mechanisms DNA extraction}

DNA extraction was done using Instagen Matrix (BioRad) as recommended by manufacturer. Shortly 1-2 colonies were homogenized in $1 \mathrm{ml}$ of distillated water and centrifuged at $10000 \mathrm{rpm}$ for 1 minute. Supernatant were discarded and pellet was homogenized with $100 \mu$ l of instagen matrix. After incubation at $55^{\circ} \mathrm{C}$ during $15-30 \mathrm{~min}$ the mixture was vortexed and incubated at $95^{\circ} \mathrm{C}$ during $8 \mathrm{~min}$. Lysate were centrifuged and $2 \mu \mathrm{l}$ of supernatant were used as DNA for PCR reactions.

\section{PCR}

Erythromycin, lincomycin, gentamycin and tetracyclin resistant MRSA isolates were tested for the presence of $m s r A, \operatorname{erm} A, \operatorname{erm} B, \operatorname{erm} C, \operatorname{lin} A, \operatorname{lin} B$, aac-aph, tet $M$ and tet $K$ genes by PCR using specific primers. List of the primers and PCR conditions are shown in Table 1 [7-11].

\section{Results}

\section{Susceptibilities to antibiotics}

MICs and resistance was evaluated using CLSI criteria [12]. All 397 MRSA isolates tested were found to be susceptible to vancomycin and linezolid. Only 8 of 397 MRSA isolates were susceptible to all antibiotics tested. In Table $2 \mathrm{MIC}_{50}$ and $\mathrm{MIC}_{90}$ of the isolates are shown for each antibiotic tested. The number of resistant isolates to erythromycin, lincomycin, tetracyclin, gentamycin, fusidik acid, ciprofloxacin and kanamycin were 225 (\%56.7), 168 (\%42.3), 350 (\% 88.2), 358 (\%90.2), 32 (\%8.1), 366 (\%92.2), and 363 (\%91.4), respectively (Table 3 ). Distribution of resistance levels for the antibiotics for each centre is shown at Table 4.

\section{Resistance mechanisms}

Of 225 erythromycin resistant MRSA isolates 48 carried ermA, 20 carried erm $C, 1$ carried both ermA and ermB, 1 carried both ermB and erm $C, 128$ carried both erm $A$ and erm $C, 2$ carried ermA, ermB and erm $C, 2$ carried $m s r A, 2$ carried $m s r A$ and erm $A, 1$ had $m s r A$ and ermB, 4 had $m s r A$, erm $A$ and erm $C, 1$ had $m s r A$ and erm $C$ genes. A total of 15 isolates were negatives for all erythromycin resistance genes tested. Among MRSA isolates 64 were intermediate resistant to erythromycin. Of these isolates 36 were positive for $\operatorname{erm} A, 1$ isolate had both ermA and ermC, and 1 isolate was positive for $m s r A$. All remaining 26 isolates were negatives for the genes tested. Among 168 lincomycin resistant isolates 9 
Table 1 Primers and PCR conditions used to amplify resistance genes

\begin{tabular}{|c|c|c|c|}
\hline Resistance genes & Primers & PCR conditions & References \\
\hline \multirow[t]{2}{*}{ ermA } & F 5'TCT AAA AAG CAT GTA AAA GAA3' & Pre cycle $93^{\circ} \mathrm{C} 3 \mathrm{~min}$ & [7] Sutcliffe 1996 \\
\hline & R 5'CTT CGA TAG TाT ATT AAT ATT AGT3' & 35 cycles: $93^{\circ} \mathrm{C} 60 \mathrm{~s}, 52^{\circ} \mathrm{C} 60 \mathrm{~s}, 72^{\circ} \mathrm{C} 60 \mathrm{~s}$ & \\
\hline \multirow[t]{2}{*}{ ermB } & F 5'GAA AAG GTA CTC AAC CAA ATA3' & Last cycle $72^{\circ} \mathrm{C} 5 \mathrm{~min}$ & \\
\hline & R 5'AGT AAC GGT ACT TAA ATT GTT TAC3' & & \\
\hline \multirow[t]{2}{*}{ ermC } & F 5'GCT AAT ATT GTT TAA ATC GTC AAT TCC3' & & \\
\hline & R 5'GGA TCA GGA AAA GGA CAT TाT AC3' & & \\
\hline \multirow[t]{3}{*}{ msrA } & F 5'GCA AAT GGT GTA GGT AAG ACA ACT3' & Pre cycle $93^{\circ} \mathrm{C} 3 \mathrm{~min}$ & [7] Sutcliffe 1996 \\
\hline & R 5'ATC ATG TGA TGT AAA CAA AAT3' & 35 cycles: $93^{\circ} \mathrm{C} 30 \mathrm{~s}, 52^{\circ} \mathrm{C} 30 \mathrm{~s}, 72^{\circ} \mathrm{C} 60 \mathrm{~s}$ & \\
\hline & & Last cycles $72^{\circ} \mathrm{C} 10 \mathrm{~min}$ & \\
\hline \multirow[t]{2}{*}{$\operatorname{lin} A$} & F 5'GTA TTA ACT GGA AAA CAG CAA AG3' & Pre cycle $5 \mathrm{dk} 94^{\circ} \mathrm{C}$ & [10] Lina 1999 \\
\hline & R 5'GAG CTT CTT TTG AAA TAC ATG G3' & 35 cycles $45 \mathrm{~s} 94^{\circ} \mathrm{C}, 45 \mathrm{~s} 54^{\circ} \mathrm{C}, 1 \mathrm{~min}$ at $72^{\circ} \mathrm{C}$ & \\
\hline \multirow[t]{2}{*}{$\operatorname{lin} B$} & F 5'CCTACCTATTGTTTGTGGAA 3' & Last cycle 5 min at $72^{\circ} \mathrm{C}$ & [11] Bozdogan 1999 \\
\hline & R 5'ATAACGTTACTCTCCTATTC 3' & & \\
\hline \multirow[t]{2}{*}{ tetM } & F 5'GTG GAC AAA GGT ACA ACG AG3' & Pre cycle $930 C^{\prime}$ de $5 \mathrm{dk}$ & [9] Warsa 1996 \\
\hline & R 5'CGG TAA AGT TCG TCA CAC AC3' & 35 cycles $93^{\circ} \mathrm{C} 60 \mathrm{~s}, 52^{\circ} \mathrm{C} 60 \mathrm{~s}, 72^{\circ} \mathrm{C} 60 \mathrm{~s}$ & \\
\hline \multirow[t]{2}{*}{ tetK } & F 5'CAG CAG ATC CTA CTC CTT3' & Last cycle $10 \mathrm{~min}$ at $72^{\circ} \mathrm{C}$ & \\
\hline & R 5'TCG ATA GGA ACA GCA GTA3' & & \\
\hline \multirow[t]{3}{*}{ aac-aph } & F 5'GAG CAA TAA GGG CAT ACC AAA AAT C3' & Pre cycle $94 C^{\prime}$ de 5 dk, & [8] Kao 2000 \\
\hline & R 5'CCG TGC ATT TGT CTT AAA AAA CTG G3' & 35 cycles $94^{\circ} \mathrm{C} 30 \mathrm{~s}, 50^{\circ} \mathrm{C} 30 \mathrm{~s}, 72^{\circ} \mathrm{C} 30 \mathrm{~s}$ & \\
\hline & & Last cycle $7 \mathrm{~min}$ at $72^{\circ} \mathrm{C}$ & \\
\hline
\end{tabular}

had ermA, 17 had erm $C, 1$ had both ermA and ermB, 1 had both ermB and erm $C, 124$ had both erm $A$ and erm $C, 4$ had $m s r A$, erm $A$ and erm $C, 2$ had erm $A$, erm $B$ and $e r m C, 1$ had $\operatorname{lin} A$ and $m s r A, 1$ had erm $C$ and $m s r A$ genes found and 8 isolates were negative by PCR for the genes tested. All lincomycin resistant isolates were tested for clindamycin inactivation by Gots' test and 3 isolates were found to be positive for inactivation. Of these 3 isolates one carried $\operatorname{lin} A$ gene responsible for lincosamide inactivation and also $m s r A$ gene, but remaining 2 isolates were negatives for both $\operatorname{lin} A$ and $\operatorname{lin} B$ genes.

Table 2 MIC $_{50}$, and MIC $_{90}$ values for antibiotics tested for MRSA isolates

\begin{tabular}{lll}
\hline Antibiotics & $\mathbf{M I C}_{\mathbf{5 0}} \mathbf{( \mathbf { m g } / \mathbf { L } )}$ & $\mathbf{M I C}_{\mathbf{9 0}} \mathbf{( \mathbf { m g } / \mathbf { L } )}$ \\
\hline Tetracyclin & 128 & 128 \\
Ciprofloxacin & $>64$ & $>64$ \\
Linezolid & 2 & 2 \\
Fusidic Acid & 0.25 & 0.5 \\
Vancomycin & 1 & 2 \\
Kanamycin & $>128$ & $>128$ \\
Erythromycin & 16 & $>128$ \\
Lincomycin & 1 & $>128$ \\
Gentamycin & 64 & 128 \\
\hline
\end{tabular}

Among macrolide resistant isolates the most frequently encountered gene was ermA (185 isolates) folloved by erm $C$ (157 isolates), $m s r A$ (10 isolates) and ermB (9 isolates).

A total of 358 isolates were resistant to gentamycin and 334 of these isolates were positive for aac-aph gene and remaining 24 isolates were negative for this gene.

It was found that 350 of 397 isolates were resistant to tetracyclin. Of these 350 isolates 314 carried tet $M$ gene and 36 did not carry this gene. Among tet $M$ negative 36 isolates 10 had tet $K$ gene and remaining 26 isolates were negative both tet $M$ and tet $K$. Distribution of resistance genes among resistant isolates are shown in Table 5. Among macrolide resistance isolates the most common gene combination was ermA-ermC. Among tetracyclin and gentamycin resistant isolates the most common resistant genes were tet $M$ and $a a c$-aph, respectively.

\section{Discussion}

Antibiotic resistance became an important public health problem in Turkey as it is in whole world. Restriction of beta lactam use in MRSA isolates required use of other types of antibiotics for the treatment of infections due to MRSA isolates so survey of susceptibilities of MRSA isolates for antibiotics other than beta lactams became very important.

Our study is the largest study done in Turkey which evaluates both phenotypic and genotypic aspect 
Table 3 Prevalence of resistance rates of 397 MRSA isolates

\begin{tabular}{llll}
\hline Antibiotics & \multicolumn{3}{l}{ Number of isolate (\%) } \\
\cline { 2 - 4 } & $\begin{array}{l}\text { Resistance } \\
\text { rates }\end{array}$ & $\begin{array}{l}\text { Intermediate } \\
\text { resistance rates }\end{array}$ & $\begin{array}{l}\text { Susceptibility } \\
\text { rates }\end{array}$ \\
\hline Erythromycin & $225(56.7)$ & $64(16.1)$ & $108(27.2)$ \\
Lincomycin & $168(42.3)$ & $66(16.6)$ & $163(41.1)$ \\
Tetracyclin & $350(88.2)$ & 0 & $47(11.8)$ \\
Ciprofloxacin & $366(92.2)$ & $4(1)$ & $27(6.8)$ \\
Kanamycin & $363(91.4)$ & $1(0.3)$ & $33(8.3)$ \\
Gentamycin & $358(90.2)$ & $5(1.3)$ & $34(8.5)$ \\
Fusidic Acid & $32(8.1)$ & 0 & $365(91.9)$ \\
Linezolid & 0 & 0 & $397(100)$ \\
Vancomycin & 0 & 0 & $397(100)$ \\
\hline
\end{tabular}

of antimicrobial resistance among MRSA. A study done in Harran University, Urfa at 2004 indicated that erythromycin, clindamycin, gentamycin and ciprofloxacin resistant among MRSA isolates $63 \%, 50 \%, 81 \%$ and $25 \%$, respectively [13]. Other study done at Manisa, at 2007 evaluated resistance of MRSA isolated from 1998 to 2002 [14]. It was shown that erythromycin resistance decreased from $59.5 \%$ to $51 \%$, clindamycin resistance increased from $28.4 \%$ to $41.5 \%$, tetracyclin resistance increased from $57.6 \%$ to $88 \%$, and gentamycin resistance from $28.4 \%$ to $\%$ 87.5, ciprofloxacin resistance from $34.1 \%$ to $92.2 \%$. Our study confirmed the tendency for increase in the resistance level of ciprofloxacin, tetracyclin and gentamycin. Saribas et al. investigated macrolide resistance genes among MRSA isolates and showed that macrolide resistance level was $29.9 \%$ and $86 \%$ of the resistant isolates carried ermA gene [15]. Saribaş et al. found resistance level lower than our study and other studies from Turkey however resistance gene profile was similar with $86 \%$ of ermA gene but in our study more than $50 \%$ of ermA positive isolates also carried erm $C$ gene. Gül et al. evaluated erythromycin resistance rate among MRSA isolated between 2003-2006 and found resistance rate as $84.9 \%$ [16]. Of resistant isolates $37.7 \%$ had ermA $26.6 \%$ had ermC and $18.6 \%$ had both ermA and ermC [16]. Aktaş et al. studied 22 erythromycin resistant MRSA isolated in Istanbul and found thet the most frequent genotype was presence of both ermA and ermC 40.9(\%) followed by ermC (18.2\%) [17]. Ardiç et al. also found among 28 erythromycin resistant MRSA that presence of both ermA and ermC was the most frequent genotype [18].

In the world among erythromycin resistant MRSA isolates ermA was the most frequent gene in France (57.6\%) [10], Colombia (78.5\%) [19] and Malesia (52.8\%) [20] but in Greece which is neighbour of Turkey ermC (96.5\%) [21] found to be the most frequent gene.

In our study the most frequent mechanism of macrolide resistance among MRSA isolates found to be presence of methylase. Presence of methylase may confer inducible lincomycin resistance which should be taken in consideration for treatment design. The dominant genes among tetracyclin and aminoglycoside resistant isolates were tet $M$ and aac-aph, respectively.

The dissemination of resistance was also analysed at regional level. İsolates from Istanbul had lower tetracycline resistance than other regions. MRSA isolates from Van had higher macrolide resistance rates than other regions. Ciprofloxacin resistance rates were very high in all centers

Table 4 Resistance rates by centre of MRSA isolates

\begin{tabular}{|c|c|c|c|c|c|c|c|c|c|}
\hline \multirow[b]{2}{*}{ Centre (No of isolates) } & \multicolumn{9}{|c|}{$\%$ of resistant isolates } \\
\hline & Tetra** & Cipro & Line & F. Acid & Vanco & Kana & Erythro & Linco & Genta \\
\hline Aydın (15) & 86.6 & 100 & 0 & 0 & 0 & 100 & 80 & 60 & 93.3 \\
\hline İmir (17)A* & 94.1 & 100 & 0 & 5.8 & 0 & 100 & 52.9 & 64.7 & 88.2 \\
\hline İzmir (22)B* & 95.4 & 100 & 0 & 9.1 & 0 & 90.9 & 72.7 & 63.6 & 90.9 \\
\hline Afyon (23) & 91.3 & 86.9 & 0 & 21.7 & 0 & 86.9 & 21.7 & 26.1 & 82.6 \\
\hline Manisa (23) & 95.6 & 86.9 & 0 & 0 & 0 & 95.6 & 69.5 & 56.5 & 91.3 \\
\hline $\operatorname{Van}(42)$ & 95.2 & 97.6 & 0 & 2.4 & 0 & 95.2 & 4.7 & 2.4 & 92.8 \\
\hline Trabzon (54) & 88.9 & 74.1 & 0 & 12.9 & 0 & 70.3 & 52.7 & 40.7 & 68.5 \\
\hline Samsun (51) & 98 & 94.1 & 0 & 7.8 & 0 & 92.1 & 45.1 & 31.3 & 90.2 \\
\hline Ankara (31) & 100 & 100 & 0 & 0 & 0 & 96.7 & 58 & 41.9 & 80.6 \\
\hline Konya (28) & 92.8 & 96.4 & 0 & 10.7 & 0 & 96.4 & 89.3 & 46.2 & 92.8 \\
\hline İstanbul (55) & 52.7 & 96.3 & 0 & 3.6 & 0 & 96.3 & 56.3 & 58.2 & 96.3 \\
\hline Edirne (36) & 88.8 & 88.8 & 0 & 8.3 & 0 & 88.8 & 50 & 41.6 & 88.8 \\
\hline Toplam (397) & 88.2 & 92.2 & 0 & 8.1 & 0 & 91.4 & 56.7 & 42.3 & 90.2 \\
\hline
\end{tabular}

*A: Katip Celebi University Bozyaka Hospital, B: Izmir Atatürk State Hospital.

**Tetra, Tetracycline; Cipro, Ciprofloxacin; Line, Linezolid; F. Acid, Fusidic Acid; Vanco, Vancomycin; Kana, Kanamycin, Erythro, Erythromycin; Linco, Lincomycin; Genta; Gentamycin. 
Table 5 Distribution of resistance genes

\begin{tabular}{|c|c|c|c|c|c|c|c|c|c|}
\hline \multirow{3}{*}{$\begin{array}{l}\text { Number of Resistant } \\
\text { isolates (\%) }\end{array}$} & \multicolumn{9}{|l|}{ Antibiotics } \\
\hline & Erythro* & Linco & Tetra & Genta & Cipro & Line & F. Acid & Vanco & Kana \\
\hline & $225(56.7)$ & $168(42.3)$ & $350(88.2)$ & $358(90.2)$ & $366(92.2)$ & $0(0)$ & $32(8.1)$ & $0(0)$ & 363 (91.4) \\
\hline \multirow[t]{12}{*}{ Gene (\%) } & ermA (21.3) & ermA (5.4) & tetM (90) & aac-aph (93) & $N D^{* *}$ & ND & ND & ND & ND \\
\hline & ermB (0) & ermB (0) & tetk (2.9) & & & & & & \\
\hline & ermC (8.9) & ermC (10.1) & & & & & & & \\
\hline & ermA-B (0.4) & $\operatorname{erm} A-B(0.6)$ & & & & & & & \\
\hline & ermB-C (0.4) & ermB-C (0.6) & & & & & & & \\
\hline & ermA-C (56.9) & ermA-C (73.8) & & & & & & & \\
\hline & ermA-B-C (0.9) & ermA-B-C ( 1.2) & & & & & & & \\
\hline & msrA (0.9) & msrA (0) & & & & & & & \\
\hline & msra,ermA (0.9) & $m s r A, e r m A(0)$ & & & & & & & \\
\hline & $m s r A$, ermB (0.4) & $m s r A, \operatorname{ermB}(0)$ & & & & & & & \\
\hline & msrA,ermC (0.4) & msrA,ermC (0.6) & & & & & & & \\
\hline & msrA,ermA-C (1.8) & msrA,ermA-C (2.4) & & & & & & & \\
\hline $\operatorname{lin} A, m s r A(0.6)$ & Unknown (6.6) & Unknown (4.7) & Unknown (7.1) & Unknown (7) & & & & & \\
\hline
\end{tabular}

*Erythro, Erythromycin; Linco, Lincomycin; Tetra, Tetracycline; Genta, Gentamycin; Cipro, Ciprofloxacin; Line, Linezolid; F. Acid, Fusidic Acid; Vanco, Vancomycin; Kana, Kanamycin.

**ND; Not Determined.

and the lowest rate was in Trabzon with 74\% and highest rates were in Aydın, Ankara and Izmir with 100\%. Tetracyclin resistance was lowest in Istanbul with 52.7\% and highest in Ankara with 100\%. Fusidic acid resistance rates were relatively low. All isolates from Ankara, Aydin and Manisa were susceptible to fusidic acid, and highest resistance rate was in Afyon with 21.7\%. Erythromycin resistance was lowest at Van with $4.7 \%$ and highest at Konya with $89.3 \%$. At the same time Konya was the center where the resistance rate differences were the highest between erythromycin and lincomycin. Resistance rates were the lowest in Afyon and Samsun with $<50 \%$. Lincomycin resistance rate was 46.2\%. Resistance to gentamycin was lowest in Trabzon with $68.5 \%$ and highest in Istanbul with $96.3 \%$.

In our study the most common gentamycin resistance gene was aac-aph gene (96\%). Ardıç et al. studied with 17 gentamycin resistant MRSA isolates from Istanbul at 2006 and found 16 of $17(94,1 \%)$ isolate carried aac-aph gene [22]. A study from Iran, neighbour state of Turkey, showed that isolates from Tehran aac-aph gene was the most common gene among gentamycin resistant S. aureus (83\%) [23]. Tetracyclin resistance gene tetM was $90 \%$ positive among tetracyclin resistant isolates which were only $49 \%$ among resistant isolates from Malesia [20].

\section{Conclusion}

Our study is one of the largest epidemiological study done in Turkey. These multi-centre data of resistance level and mechanism of resistance of MRSA isolates will be important for future surveillance studies to determine the evolution of resistance levels and mechanisms at national and regional level. Also our results and follow up studies may constitute a database for empirical treatment of infections due to MRSA. Our multicentre study showed that isolates from 12 centres from Turkey had multiple resistances. Quinolone and gentamycin resistance found to be very high. Fusidic acid resistance was low and erythromycin and lincomycin susceptibility found to be relatively high. This study indicated that resistance to linezolid and vancomycin resistance is not emerged among MRSA isolates from Turkish hospitals.

\section{Competing interests}

The authors declare that they have no competing interest.

\section{Authors' contributions}

AYÇ, AGS, SAC, GB, HG, MÖ, MTO, NK, NÖ, OA, SÖ and UA participated of collection and identification of MRSA isolates. MIC testing and genetic studies were done by ÖY and BB, and manuscript draft was prepared by ÖY and BB. All authors read and approved the final manuscript.

\section{Acknowledgement}

This study was supported by grant TPF09025 from Adnan Menderes University BAP.

\section{Author details}

'ADU BILTEM Epidemiology Unit, Aydin, Turkey. ${ }^{2}$ Medical Faculty Medical Microbiology Department, Ondokuz Mayıs University, Samsun, Turkey. ${ }^{3}$ Katip Çelebi University, Atatürk Training and Research Hospital, Izmir, Turkey. ${ }^{4}$ Bozyaka Training and Research Hospital, Izmir, Turkey. ${ }^{5}$ Medical Faculty Medical Microbiology Department, Karadeniz Technical University, Trabzon, Turkey. ${ }^{6}$ Medical Faculty Medical Microbiology Department, Yüzüncü YIl University, Van, Turkey. ${ }^{7}$ GATA Haydarpaşa Training Hospital, Istanbul, Turkey. ${ }^{8}$ Medical Faculty Medical Microbiology Department, Canakkale Onsekiz Mart University, Çanakkale, Turkey. ${ }^{9}$ Yüksek Ihtisas Hospital, Ankara, Turkey.

${ }^{10}$ Medical Faculty Medical Microbiology Department, Celal Bayar University, 
Manisa, Turkey. ${ }^{11}$ Medical Faculty Medical Microbiology Department, Afyon Kocatepe University, Afyon, Turkey. ${ }^{12}$ Medical Faculty Infectious Disease and Clinical Microbiology Department, Adnan Menderes University, Aydın, Turkey. ${ }^{13}$ Medical Faculty Medical Microbiology Department, Selçuk University, Konya, Turkey. ${ }^{14}$ Medical Faculty, Medical Microbiology Department, Adnan Menderes University, 09010 Aydin, Turkey.

Received: 9 May 2014 Accepted: 28 August 2014

Published online: 16 September 2014

\section{References}

1. Gould IM, David MZ, Esposito S, Garau J, Lina G, Mazzei T, Peters G: New insights into meticillin-resistant Staphylococcus aureus (MRSA) pathogenesis, treatment and resistance. Int J Antimicrob Agents 2012, 39(2):96-104.

2. Neu HC: The crisis in antibiotic resistance. Science 1992, 257:1064-1068.

3. Bozdogan B, Ednie L, Credito K, Kosowska K, Appelbaum PC: Derivatives of a vancomycin-resistant Staphylococcus aureus strain isolated at Hershey Medical Center. Antimicrob Agents Chemother 2004, 48(12):4762-4765.

4. Türkyılmaz S, Tekbiyık S, Oryasin E, Bozdogan B: Molecular Epidemiology and Antimicrobial Resistance Mechanisms of Methicillin-Resistant Staphylococcus aureus Isolated from Bovine Milk. Zoonoses Public Health 2010, 57:197-203.

5. CLSI: Methods for Dilution Antimicrobial Susceptibility Tests for Bacteria That Grow Aerobically; Approved Standard -Ninth Edition. CLSI document M29-A3 ISBN 1-56238-784-7. Clinical and Laboratory Standards Institute; 2012.

6. Gots JS: The detection of penicillinase production properties of microorganisms. Science 1945, 102:309.

7. Sutcliffe J, Grebe T, Tait-Kamradt A, Wondrack L: Detection of erythromycin-resistant determinants by PCR. Antimicrob Agents Chemother 1996, 40:2562-2566.

8. Kao SJ, You I, Clewell DB, Donabedian SM, Zervos MJ, Petrin J, Shaw KJ, Chow JW: Detection of the high-level aminoglycoside resistance gene aph (2")-Ib in Enterococcus faecium. Antimicrob Agents Chemother 2000, 44:2876-2879.

9. Warsa UC, Nonoyama M, Ida T, Okamoto R, Okubo T, Shimauchi C, Kuga A, Inoue $\mathrm{M}$ : Detection of tet $(\mathrm{K})$ and tet $(\mathrm{M})$ in Staphylococcus aureus of Asian countries by the polymerase chain reaction. J Antibiot 1996, 49:1127-1132.

10. Lina G, Quaglia A, Reverdy ME, Leclercq R, Vandenesch F, Etienne J: Distribution of genes encoding resistance to macrolides, lincosamides, and streptogramins among staphylococci. Antimicrob Agents Chemother 1999, 43:1062-1066.

11. Bozdogan B, Berrezouga L, Kuo MS, Yurek DA, Farley KA, Stockman BJ, Leclerca R: A new resistance gene, linB, conferring resistance to lincosamides by nucleotidylation in Enterococcus faecium HM1025. Antimicrob Agents Chemother 1999, 43:925-929.

12. Clinical and Laboratory Standards Institute: Methods for dilution antimicrobial susceptibility tests for bacteria that grow aerobically, 6th ed. Approved standard M7-A6. Wayne, PA: Clinical and Laboratory Standards Institute; 2003.

13. Sirmatel F, Ylddz Zeyrek F, Erkmen O: Antibiotic resistance in nosocomial Staphylococcus strains with broth microdilution method. ANKEM Derg 2004, 18:200-204.

14. Kurutepe S, Sürücüoğlu S, Gazi H, Teker A, Özbakkaloğlu B: Antibiotic resistance rates of methicillin resistant and susceptible Staphylococcus aureus strains. Turk J Infect 2007, 21:187-191.

15. Sarıbaş Z, Tunçkanat F, Özçakır O, Ercis S: Investigation of macrolide-lincosamide-streptogramin B (MLS(B)) and telithromycin resistance in clinical strains of staphylococci. Mikrobiyol Bul 2010, 44:177-186.

16. Gul HC, Kilic A, Guclu AU, Bedir O, Orhon M, Basustaoglu AC: Macrolide-lincosamide-streptogramin B resistant phenotypes and genotypes for methicillin-resistant Staphylococcus aureus in Turkey, from 2003 to 2006. Pol J Microbiol 2008, 57:307-312.

17. Aktas Z, Aridogan A, Kayacan CB, Aydin D: Resistance to macrolide, lincosamide and streptogramin antibiotics in staphylococci isolated in Istanbul, Turkey. J Microbiol 2007, 45:286-290.

18. Ardic N, Ozyurt M, Sareyyupoglu B, Haznedaroglu T: Investigation of erythromycin and tetracycline resistance genes in methicillin-resistant staphylococci. Int J Antimicrob Agents 2005, 26:213-218.
19. Reyes J, Hidalgo M, Díaz L, Rincón S, Moreno J, Vanegas N, Castañeda E, Arias CA: Characterization of macrolide resistance in Gram-positive cocci from Colombian hospitals: a countrywide surveillance. Int $J$ Infect Dis 2007, 11:329-336.

20. Lim KT, Hanifah YA, Yusof MYM, Thong KL: ermA, ermC, tetM and tetK are essential for erythromycin and tetracycline resistance among methicillin-resistant Staphylococcus aureus strains isolated from a tertiary hospital in Malaysia. Indian J Med Microb 2012, 30:203-207.

21. Spiliopoulou I, Petinaki E, Papandreou P, Dimitracopoulos G: erm(C) is the predominant genetic determinant for the expression of resistance to macrolides among methicillin-resistant Staphylococcus aureus clinical isolates in Greece. J Antimicrob Chemother 2004, 53:814-817.

22. Ardic N, Sareyyupoglu B, Ozyurt M, Haznedaroglu T, Ilga U: Investigation of aminoglycoside modifying enzyme genes in methicillin-resistant staphylococci. Microbiol Res 2006, 161:49-54.

23. Fatholahzadeh B, Emaneini M, Feizabadi MM, Sedaghat H, Aligholi M, Taherikalani M, Jabalameli F: Characterisation of genes encoding aminoglycoside-modifying enzymes among meticillin-resistant Staphylococcus aureus isolated from two hospitals in Tehran, Iran. Int J Antimicrob Agents 2009, 33:264-265.

doi:10.1186/s12941-014-0044-2

Cite this article as: YIldı et al:: Antimicrobial susceptibility and resistance mechanisms of methicillin resistant Staphylococcus aureus isolated from 12 Hospitals in Turkey. Annals of Clinical Microbiology and Antimicrobials 2014 13:44.

\section{Submit your next manuscript to BioMed Central and take full advantage of:}

- Convenient online submission

- Thorough peer review

- No space constraints or color figure charges

- Immediate publication on acceptance

- Inclusion in PubMed, CAS, Scopus and Google Scholar

- Research which is freely available for redistribution 